\title{
Article \\ The Interdisciplinary Approach of Some Middle Bronze Age Pottery from Eastern Romania
}

\author{
Ana Drob ${ }^{1,2} \mathbb{D}$, Viorica Vasilache ${ }^{1, *} \mathbb{( D}$ and Neculai Bolohan ${ }^{3}$ \\ 1 Institute of Interdisciplinary Research-Interdisciplinary Sciences Department, ARHEOINVEST Center, \\ "Alexandru Ioan Cuza", University of Iași, Bld Carol I no. 11, 700505 Iași, Romania; ana.drob@uaic.ro \\ 2 Doctoral School of History, Faculty of History, "Alexandru Ioan Cuza", University of Iași, Bld Carol I no. 11, \\ 700505 Iași, Romania \\ 3 Faculty of History, "Alexandru Ioan Cuza", University of Iași, Bld Carol I no. 11, 700505 Iași, Romania; \\ neculai.bolohan@uaic.ro \\ * Correspondence: viorica_18v@yahoo.com
}

Citation: Drob, A.; Vasilache, V.; Bolohan, $\mathrm{N}$. The Interdisciplinary Approach of Some Middle Bronze Age Pottery from Eastern Romania. Appl. Sci. 2021, 11, 4885. https:// doi.org/10.3390/app11114885

Academic Editor: Filomena De Leo

Received: 10 May 2021

Accepted: 25 May 2021

Published: 26 May 2021

Publisher's Note: MDPI stays neutral with regard to jurisdictional claims in published maps and institutional affiliations.

Copyright: (c) 2021 by the authors. Licensee MDPI, Basel, Switzerland. This article is an open access article distributed under the terms and conditions of the Creative Commons Attribution (CC BY) license (https:// creativecommons.org/licenses/by/ $4.0 /)$.
Abstract: Prehistoric pottery is the most abundant material discovered in archaeological sites and represents the main element of knowledge about human communities from the past. This study presents a model of interdisciplinary investigation of pottery through several types of analyses, enabling the scientific study of this category of artifacts. The analyses were performed on 11 ceramic fragments from the Middle Bronze Age settlement of Piatra Neamț-Lutărie, Eastern Romania, considering information about the color, production technique, type, size, functionality and category of the vessel, but also data related to ceramic paste inclusions. The samples were studied by optical microscopy (OM), scanning electron microscopy (SEM) coupled with energy-dispersive X-ray analysis (EDX) and micro-Fourier-transform infrared spectroscopy ( $\mu$ FTIR). The results obtained provide important information regarding pottery manufacturing technologies, such as sources of the raw materials and firing temperatures, and revealed the functionality of various vessel categories within a prehistoric settlement.

Keywords: middle bronze age; eastern Romania; pottery; macroscopic analysis; OM; SEM-EDX; $\mu$ FTIR

\section{Introduction}

Using the archaeological methodology, we know a repertoire of seven vessel categories for Costisa and six vessel categories for Monteoru. Some of these vessels are also found in the group of fragments from Piatra Neamț-Lutărie. This approach is built on a case study that includes archaeological knowledge and aims to identify the physical and chemical characteristics specific to the pottery of a site in an area of interaction. In the same context, the present study proposes a scientific recovery and interdisciplinary analysis of a group of ceramic fragments to enlighten the history of a site, which we do not have much data.

The ceramic fragments analyzed belong to the Middle Bronze Age (1955/1879-1630/1614 BC) [1-3]. From an archaeological point of view, these materials are characteristic of the local Costisa community, with the possibility of some southern Monteoru pottery. These two Bronze Age communities were overlapping in the Subcarpathian area of Moldavia, where they coexisted both in individual settlements but also within the same one. Although some scholars have tried to highlight the existence of conflicts between these communities [4,5], recent research has disproved this hypothesis [6-8]. Thus, in this paper, the pottery of these communities is studied to identify their behavior in terms of similarities or differences concerning the pottery technologies they used, which could indicate the nature of the relationship between these two communities. Moreover, there is relatively little information about the everyday life of these groups, as no details are known about producing pottery, the process of manufacturing and pyrotechnology, aspects that will be studied in this work. 
This paper presents the interdisciplinary study of 11 ceramic fragments from the Piatra Neamț-Lutărie site through several types of analyses. Thus, they were first investigated macroscopically, taking into account a series of information, such as color, production technique, type, size, category of the vessel and functionality, but also data related to inclusions (type, size, frequency, shape). Regarding the chemical composition and other microelements, several analytical techniques were used, such as OM, SEM-EDX and $\mu$ FTIR. The results obtained from interdisciplinary analyses provide data on the nature of the raw material, firing technologies, and data on the functionality of the vessels.

\section{Materials and Methods}

\subsection{Site Information}

The site from Piatra Neamț-Lutărie $[9,10]$ is located in Eastern Romania (Figure 1), in the hydrographic basin of the Bistrița river (GPS: N 46 $56^{\prime} 08.13^{\prime \prime}$; E $26^{\circ} 23^{\prime} 03.06^{\prime \prime}$ ), which represents the main prehistoric communication route in this area. This settlement was excavated in 1957, leading to the discovery of archeological artifacts from the Eneolithic, Bronze Age and Iron Age periods and the II-III centuries AD. Information on the Costișa habitation is scarce, with no mention of living structures or firing installations assigned to this community. The settlement dimensions are unclear because the site was affected by landslides and the rescue archaeological excavation area was approximately $200 \mathrm{~m}^{2}$. From this area were recovered only ceramic fragments. Other types of objects attributed to the middle bronze age period are not mentioned. Moreover, in the 1959 report, it is specified that some archaeological complexes were affected by the "flooded soil," and the archaeological material was mixed [9].

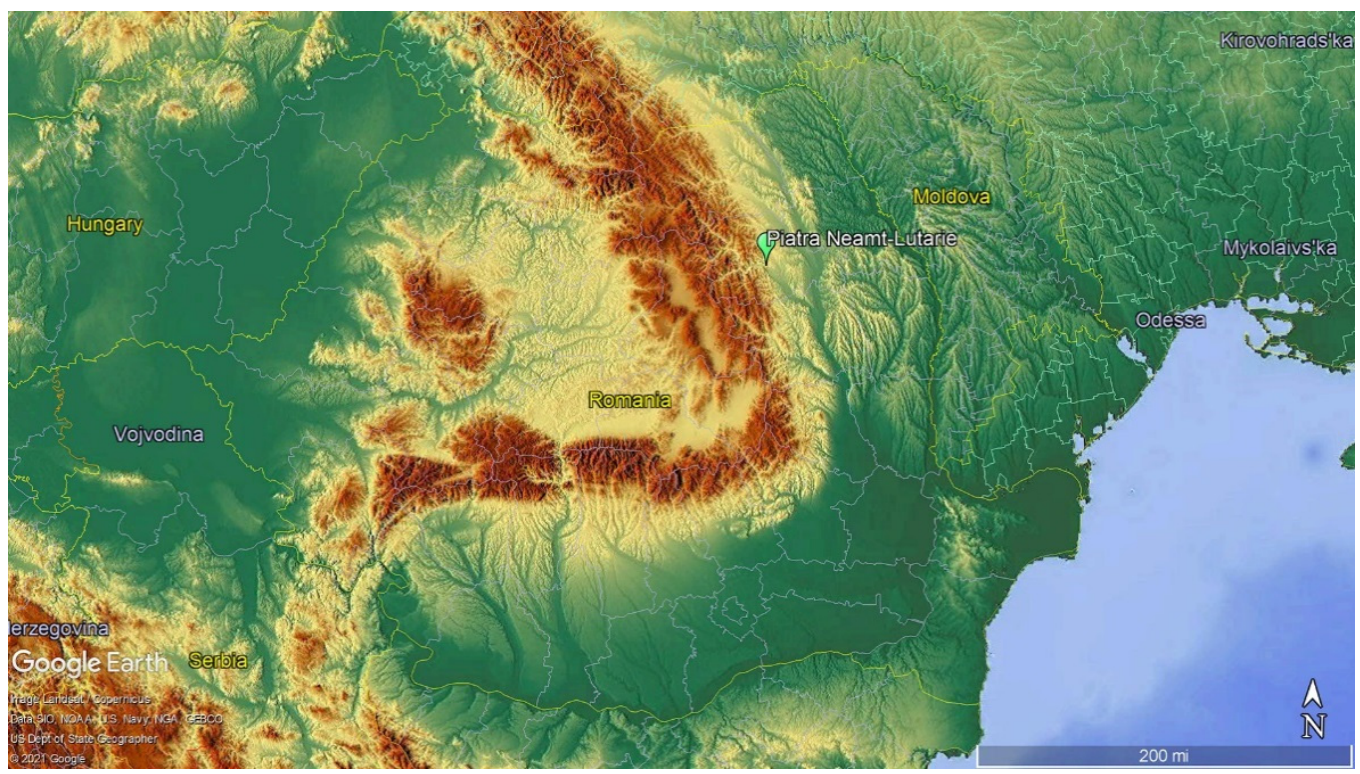

Figure 1. Geographical location of the Piatra Neamț-Lutărie settlement.

Geologically, the site area is located on Paleogene deposits (Oligocene), consisting of clays, breccias, sandstone and conglomerates. In the western part of the site, represented by the Pietricica peak, Paleogene deposits are composed of sandstone-shale flysch, bituminous flysch with Kliwa sandstones, and conglomerates. To the east, the area is made up of Quaternary formations (Pleistocene) consisting of sands, gravels, boulders and loess deposits [11]. Pedologically, in the settlement area and in its vicinity, there are only chernozems [12]. Therefore, the settlement from Piatra Neamț-Lutărie is located in a geological area rich in raw clay materials that could be used in pottery making and fertile soils used in agricultural activities. 


\subsection{Methodology}

The pottery fragments were discovered in 1957 recovered from depths between $-0.55 \mathrm{~m}$ and $-1.50 \mathrm{~m}$. The materials are in the repositories of the Museum of History and Archeology Piatra-Neamt. In this regard, some of the methodological limitations of this study should be mentioned. First of all, these 11 fragments studied are the only existing ceramic materials from this site, which did not allow the analysis of a more consistent database that would enable more comprehensive analysis. The small number of ceramic fragments is most likely caused by excavation or storage deficiencies because, in the other known Costisa sites, the appreciable amount of pottery is completed by other objects, such as those made of bone, stone or bronze. Second, the small number of preserved ceramic fragments also determined the size of the samples taken so that they were no larger than 2-3 cm, which unfortunately did not permit a complex petrographic study. As an extensive petrographic study could not be performed, the information on mineralogy will be limited to microscopic observations, which are supplemented by the results of chemical analyses, in particular the data provided by the FT-IR analysis. In addition, to these issues can be added an extremely small number of archaeometric studies for the Middle Bronze Age pottery in the eastern Carpathian area, which could have been used as a reference basis for the present study. However, even in the case of these limitations, the ceramic materials from the old excavations can be capitalized through such archaeometric studies, which contribute to the understanding of certain technological aspects involved in the processes of making prehistoric pottery in the eastern Carpathian area.

The 11 pottery fragments analyzed were marked with the letter L (Lutărie) and with numbers from 1-10. They all belong to Costișa ceramic group. They were fragments of liquid transport or storage vessels (L1), cooking (L2, L3, L4, L8), storage (L5, L6, L7) and serving vessels (L9, L10) (Figure 2). The Monteoru ceramic group is represented by a single fragment of liquid transport or storage vessel, noted L11 (Figure 2/L11). All the fragments were studied macro- and microscopically, but also by SEM-EDX and $\mu$ FTIR analyses.
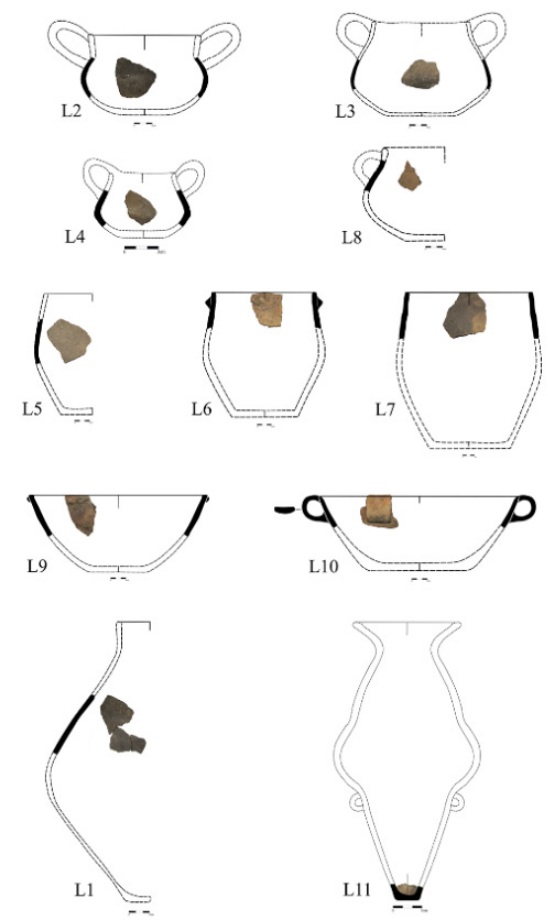

Figure 2. The analyzed pottery samples from the Piatra Neamț-Lutărie.

\subsubsection{Macroscopic Analyses}

The analysis criteria used are a standard for macroscopic investigations. Thus, for this type of approach, the following elements were considered: the color of fragments, shape/type of 
vessel, modeling technique, wall thickness, functionality, hardness, surface, surface treatment and firing atmosphere [13].

The color is determined through the Munsell Soil Color Charts, which allows a neutral rendering of nuances [14].

The shape and type of the vessels are important for identifying the technological features of different ceramic categories. Moreover, there were attempts to identify the production techniques used to manufacture the vessels [15] by studying the edges and surfaces of the ceramic fragment [16].

Measuring the vessel wall thickness is an important step because it is an indicator of its functionality and the technical skills of prehistoric potters [13,17].

Regarding the functionality of the vessels, relevant publications were considered trying to determine whether the functional criteria known through ethnoarchaeology $[18,19]$ and experimental archeology are applicable in our study [20,21]

The hardness of the ceramic fragments and their surface provide important clues about the quality of the vessels, but also about technical skills and functionality [22]. These data were supplemented by information on surface treatment [23], which involved smoothing and/or burnishing [14,22,24] and ceramic slips [23].

The firing atmosphere can be oxidizing, reducing or mixed, and it has a significant effect on both the color of the paste and the resulting surfaces $[22,25]$. The aspects related to pyrotechnology provided important data about the quality of the vessels, but also about the technological knowledge involved in the production process [23].

In the paste analyses, it is necessary to identify the component inclusions [26]. They can be ceramoclasts (crushed shards), organic matter, lithoclasts (crushed stones) or clay inclusions (small pieces of unhomogenized clay) [27]. Next, it is necessary to determine their size, frequency, shape and sorting [22]. The shape of the inclusions may indicate if they are part of the raw material. In the case of an intentional addition, their shape will be angular, caused by the crushing of the materials used [13]. The sorting and shape of the inclusions indicate the homogeneity of the paste.

The homogeneity of the paste is determined by the quality of mixing and the amount of inclusions [22]. Mixing also influences the porosity of the paste. There are two types of pores: primary and secondary. The main pores are open spaces left after the clay modeling, and the secondary pores appear as a result of the burning organic matter, appearing in the form of black spots [28].

\subsubsection{OM Analyses}

Microscopic analysis of the fragments was performed with a Zeiss Imager.a1M microscope with a built-in AXIOCAM camera, which uses AxionVisionRelease 4.7.1 software. The images were obtained at $50 \times$ and $100 \times$ magnifications in the dark field for a clear view of the inclusions. Samples were sanded with a Stroers LaboPol device using discs with different granulations.

\subsubsection{SEM-EDX Analyses}

In the current analyses was used an electron microscope with SEM scan, model VEGA II LSH, produced in the Czech Republic by TESCAN, coupled with an EDX detector type QUANTAX QX2, produced in Germany by BRUKER/ROENTEC. This microscope has a tungsten electron gun that can achieve a resolution of $3 \mathrm{~nm}$ at $30 \mathrm{KV}$, with a magnification of between 30 and 1,000,000 $\times$ in "resolution" mode, the acceleration voltage between $200 \mathrm{~V}$ and $30 \mathrm{kV}$, scan speed between $200 \mathrm{~ns}$ and $10 \mathrm{~ms}$ per pixel. The working pressure is less than $1 \times 10^{-2} \mathrm{~Pa}$. The EDX detector is used for microanalysis, which allows quantitative measurements without using specific calibration standards. It has an active area of $10 \mathrm{~mm}^{2}$, analyzing sanded or irregular surfaces. The SEM micrographs obtained consisted of backscattered electrons (BSE) at $200 \times$ and $500 \times$ magnifications for ceramic paste and surfaces without being covered with metal or graphite. 


\subsection{4. $\mu$ FTIR Analyses}

The spectra were recorded with an FTIR spectrophotometer coupled with an HYPERION 1000 microscope, both equipment from Bruker Optic, Germany. The FTIR spectrophotometer is of the TENSOR 27 type, which is predominantly suitable for measurements in close IR. The standard detector is DLaTGS covers the spectral range $7500-370 \mathrm{~cm}^{-1}$, and works at room temperature. The resolution is usually $4 \mathrm{~cm}^{-1}$ but can also reach $1 \mathrm{~cm}^{-1}$. TENSOR 27 is equipped with a He-Ne laser that emits at $633 \mathrm{~nm}$ and a power of $1 \mathrm{~mW}$ and has a ROCKSOLID alignment of the interferometer. The signal/noise ratio of this device is very good. The TENSIONER is completely controlled by the OPUS software. The HYPERION 1000 microscope is an accessory that can be paired with almost any Bruker FTIR spectrophotometer. For completely nondestructive measurements, the TENSOR 27 spectrophotometer is connected to the HYPERION 1000 microscope, and, usually, the solid samples are analyzed in reflection mode. The software is OPUS/VIDEO for interactive video data acquisition. The microscope can work in both transmission and reflection, being equipped with a $15 \times$ lens. The detector is of the MCT type cooled with liquid nitrogen $\left(-196^{\circ} \mathrm{C}\right)$. The spectral range is $600-7500 \mathrm{~cm}^{-1}$, and the measured area is optimized to a diameter of $250 \mu \mathrm{m}$ with the possibility of reaching a minimum of $20 \mu \mathrm{m}$.

\section{Results and Discussions}

\subsection{Macroscopic Results}

From the category of vessels for storage and transport of liquids, there is a single pot (L1) fired in a reducing atmosphere, with a finely burnished surface. The wall thickness is $7.87 \mathrm{~mm}$. In the paste, medium-size ceramoclasts and lithoclasts, sub-angular with a distribution of $10-15 \%$, were identified. These inclusions are well mixed and integrated into the clay matrix. Lithoclasts were isolated presences and were represented by three rounded pebbles, most likely from the raw material.

The cooking vessels (L2, L3, L4, L8) were fired in a reducing atmosphere, having fine (L2, L3) and semi-fine surfaces (L4, L8). Two vessels had an outer ceramic slip as surface treatment (L4, L8), and two other pots had their exterior surface burnished with a hard object (L2, L3). The vessel L2 had a burning spot with fine cracks on the outer surface, below the line of maximum diameter, both caused by extended heat exposure. The wall thickness is between 6.97 and $7.83 \mathrm{~mm}$, and the identified inclusions in the ceramic paste are small, subrounded ceramoclasts, with a distribution of 5-10\% (L3) and medium-size ones, with a distribution of $10-15 \%$ (L2, L4). Large sub-angular inclusions were also observed, with a frequency of $10-15 \%$ (L8). In the paste of cooking vessels, mainly the secondary pores were visible, indicating a good mixing of the components.

For the category of serving vessels (L9, L10), the firing took place in a mixed environment (L9) and in an incomplete oxidizing one (L10). The L9 vessel had a ceramic slip applied on the inner surface, and the L10 has both surfaces very well smoothed. On the exterior of both containers, there were visible secondary burning spots resulted from heat exposure. The thickness of the vessel wall is between 10.56 and $11.04 \mathrm{~mm}$, and the paste of both pots have medium, sub-angular ceramoclasts with a distribution of 15-20\% (L9) and $20-25 \%$ (L10).

Storage vessels (L5, L6, L7) were fired in a reducing (L5) and mixed (L6, L7) atmosphere and had a semi-fine (L5) and semi-coarse (L6, L7) surface. Two of the vessels have their outer surface coated with a ceramic slip (L5, L6), while another vessel had its inner surface burnished with a hard tool (L7). The wall thickness is between 9.84 and $11.74 \mathrm{~mm}$, and the main inclusions are the ceramoclasts, but the lithoclasts are also present in small numbers, resulting from the raw materials. The identified ceramoclasts are large, sub-angular and have a frequency of $10-15 \%$ in the clay matrix, and the paste mixing is fair, with primary and secondary pores. On the inner surface of two vessels (L6 and L7), there are visible traces of smudging (Figure 3) caused by using these containers in the preparation of hot food, information that will be verified through chemical analyses. 

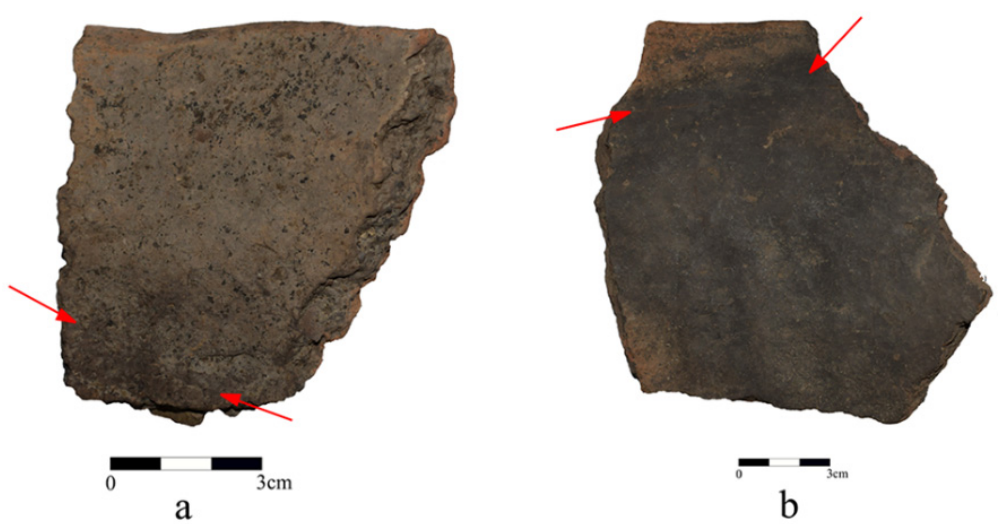

Figure 3. Storage vessels with traces of smudging (a) L6, (b) L7.

The Monteoru vessel intended for storing or transporting liquid (L11) is brown, both on the inside and the outside. It was fired in a reducing atmosphere. The wall thickness is $9.16 \mathrm{~mm}$. The fragment has a semi-fine surface and an exterior ceramic slip. The inclusions identified in the clay matrix are large-sized, subrounded, with a frequency of $10-15 \%$. On the base of the vessel, secondary burning traces are visible and a series of large pores indicating negligent mixing. In the vessel's interior, a black layer is visible that covers the entire inner surface of the fragment (Figure 4). Those residues resulted from using the vessel will be of particular interest in chemical analyses.

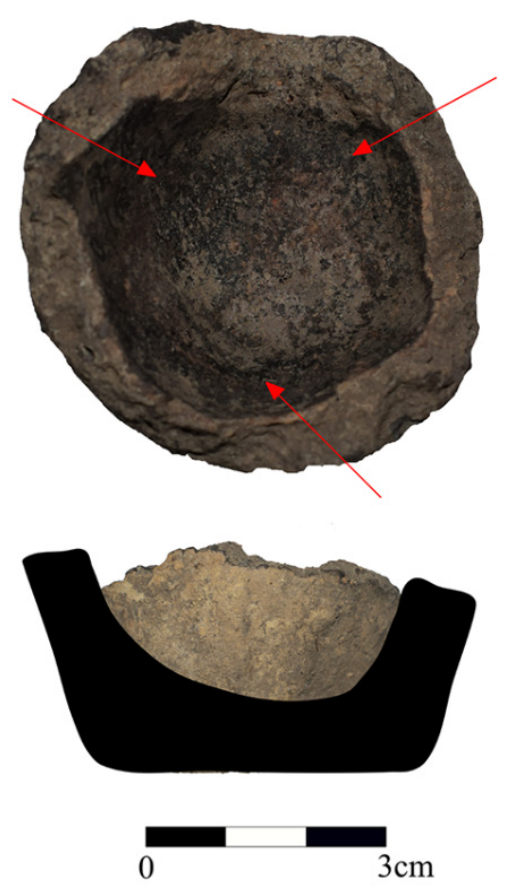

Figure 4. Sample L11 (top) interior of the vessel; (bottom) outside of the vessel.

All vessels were made by the coiling technique, as indicated by the traces of joining or by noticeable bumps, especially on the inner surface of the vessels. The auxiliary elements (handles, grips) were made by modeling. Traces of joining and finishing of these components are also visible.

Surface treatments consisted mainly of applying an external ceramic slip, noticeable in cooking and storage vessels. The same treatment is applied to the interior for the serving vessels. The outer luster was intended to waterproof cooking and liquid transporting/storing vessels, and the inner one is present in the case of a storage vessel. 
The presence of ceramoclasts is an important aspect related to the manufacture of vessels that facilitate certain functionalities. This type of inclusion is easier to break than other materials. They are already burned, which makes them more stable during the firing of the pots, and they have the same properties as the material in which they were incorporated. Therefore, it can be assumed that ceramoclasts were preferred because when they are burned, they have the same thermal characteristics and the same rate of expansion as clay, which demonstrates the prehistoric potters knew that aspect. Thus, in the paste of all the studied fragments, there are ceramoclasts present, which, depending on the functional category, have different dimensions, shapes and distributions. Based on the dimensions, shape and distribution of the main intentional inclusions, which are the ceramoclasts, three paste categories were identified. The first one, marked CP1 (Paste Category 1), is used only for cooking vessels, the inclusions being of various sizes and shapes, but the distribution in ceramic paste does not exceed $10-15 \%$. This category is also used for liquid transport or storage vessels. The second category, CP2 (Paste Category 2 ), is used for storage vessels, where the ceramoclasts are large, sub-angular and have a frequency of $10-15 \%$. The Monteoru pot was included in this category (L11). The Monteoru vessel does not present major differences in manufacturing and finishing, compared to the Costișa fragments, wherein the same inclusions with the same size, shape and frequency have been identified. The last category, CP3 (Paste Category 3), is found in serving vessels, where the ceramoclasts have a medium size, sub-angular shape and distribution of $15-25 \%$. They were found in a larger quantity than in the case of the other functional categories.

\subsection{Interdisciplinary Analyses}

OM, SEM-EDX and $\mu$ FTIR analyses were performed for all fragments, keeping the notation for the ceramic paste to differentiate the inner surface by marking it with I and the outer surface marked with $\mathrm{E}$.

\subsubsection{OM Analyses}

Through optical microscopy (Figure 5), it was observed that all the analyzed ceramic fragments contain quartz, mica and iron oxides, all representing natural inclusions from the raw material.

The presence of ceramoclasts was also detected macroscopically, but microscopically reused ceramoclasts were identified. The reused ceramoclasts result from crushing other pottery fragments, which, in their turn, also contain ceramoclasts added in the paste of the new vessels. They are present only in the case of cooking (L2, L3, L8), storage (L5, L6, L7) and serving vessels (L10).

In some ceramic fragments (L2, L3, L6, L7, L9, L10), the presence of possible plant materials as small pores and dark lamellae was observed. Visible organic matter may be the result of intentional addition or may be part of the clay used. Moreover, in all samples, the iron oxides from the raw material were identified, an important clue for identifying the type o of clay used in pottery manufacturing.

In the case of the Monteoru vessel, the black layer had multiple fine cracks, resembling a viscous, dry substance (Figure 6). Its nature will be verified, as precisely as possible, through EDX and $\mu$ FTIR analysis.

Reused ceramoclasts identified by optical microscopy indicate a concern for reusing damaged vessels and their "recycling" as inclusions of the new ones. The organic matter visible in most of the ceramic fragments could indicate the firing temperatures, which did not reach high values. The minerals identified microscopically were quartz, mica and iron oxides, which were part of the raw material clay used to manufacture pottery from Piatra Neamț-Lutărie. 

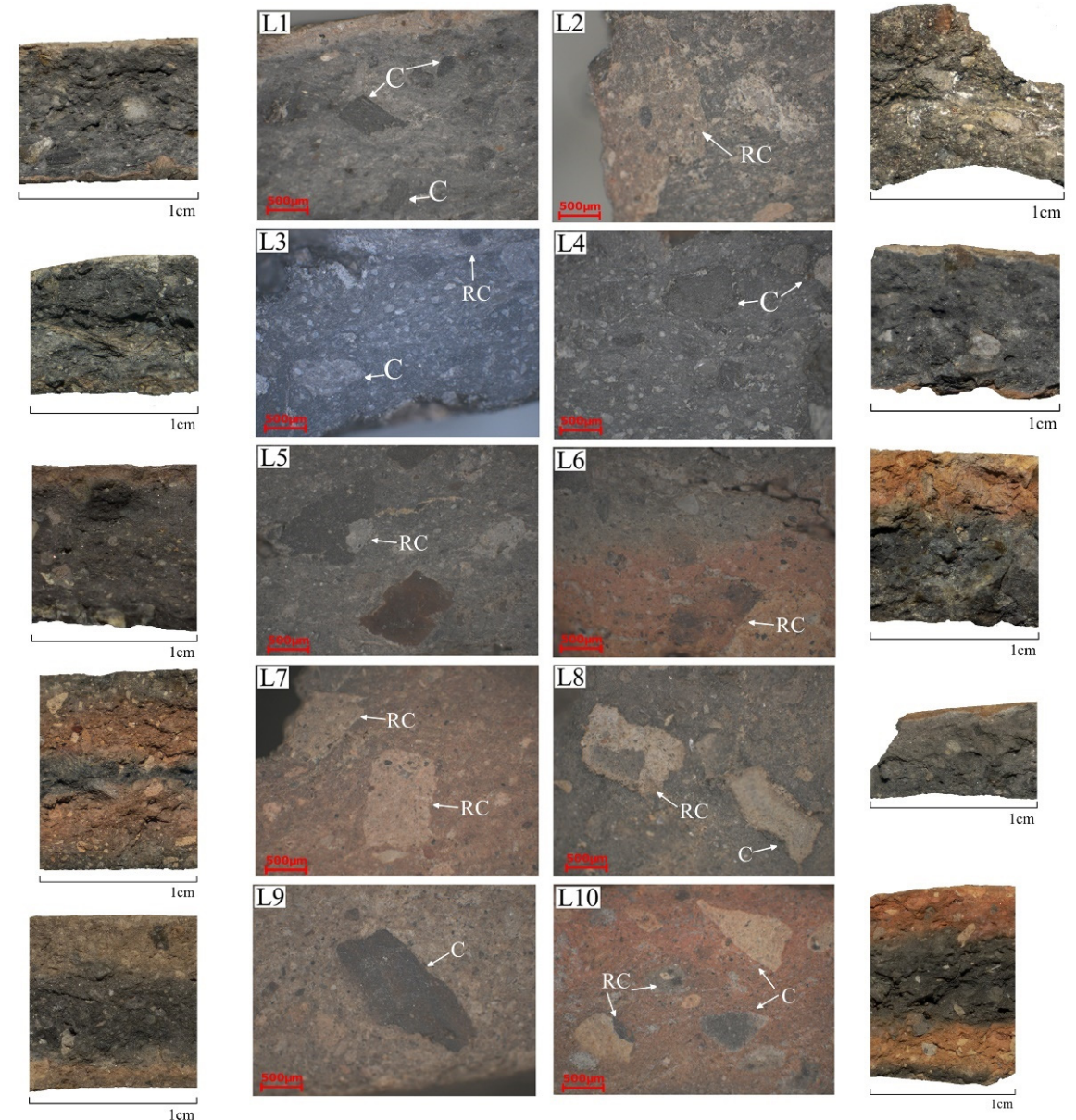

Figure 5. OM for the Costișa ceramic fragments (L1-L10) from Piatra Neamț-Lutărie (C) ceramoclasts; (RC) reused ceramoclasts).
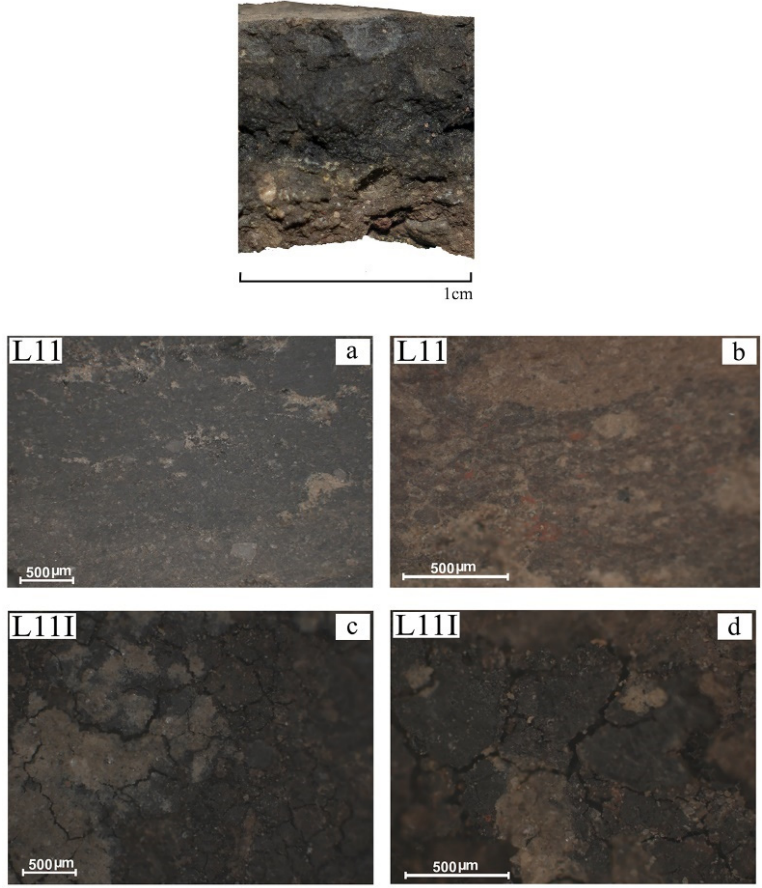

Figure 6. OM for the L11 sample $(\mathbf{a}, \mathbf{b})$ core; $(\mathbf{c}, \mathbf{d})$ inner surface with residues. 


\subsubsection{SEM-EDX Analyses}

The SEM-EDX analyses were performed both on the core and on the surfaces, keeping the notations from the OM analyses. The SEM micrographs for the core of the Costisa samples (Figures 7 and 8) show a good homogeneity of the microstructural elements, which are well incorporated in the clay matrix (L1, L4). A compact lamellar structure was also visible (L8).
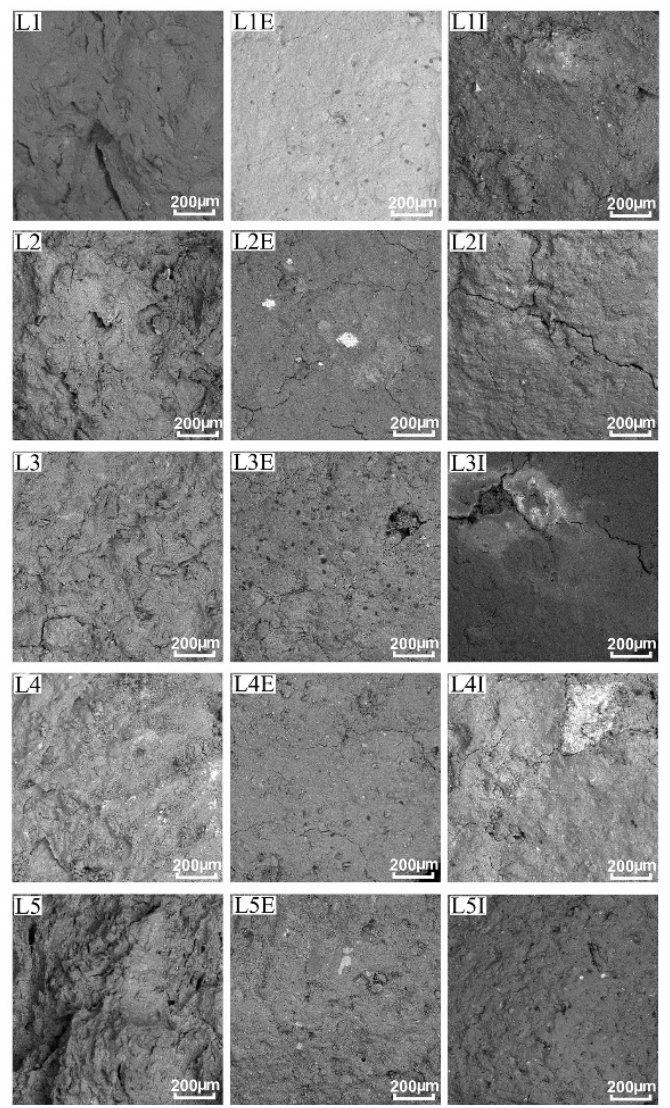

Figure 7. SEM micrographs for the Costișa ceramic fragments (L1-L5) from Piatra Neamț-Lutărie.

In most samples (L2, L3, L5, L6, L7, L9, L10), individualized mineral particles are visible, with a low homogeneity, and in other samples, traces of vegetal fibers were noticed (L7, L10), aspects that suggest relatively low firing temperatures. The SEM images also show elongated and flattened pores, present in five samples (L1, L5, L8, L9, L10), which indicate using the coiling technique in making the vessels [29].

SEM analyses of the surfaces revealed the presence of luster (Figures 7 and 8 ). This type of treatment closes ceramic pores, making the vessel walls smooth and waterproof, as noticed in the case of vessels L1, L2, L3 for the exterior and L7 for the interior. The rest of the ceramic fragments have well-smoothed surfaces, with partially covered pores and individualized mineral particles. In the case of samples L2E+I, L3I, L4E+I, L7E+I and L8E, fine cracks are visible on the surfaces, which may have resulted from using the vessel. Such traces that represent indicators of functionality are also the carbon deposits [30] on the outer surfaces of vessels L3 and L7.

The SEM micrographs for Monteoru sample L11 (Figure 9) indicate a good homogeneity, with mineral elements well incorporated in the clay mass. Carbon deposits are visible on the outer surface of the fragment, and the black layer was observed on the inside. 


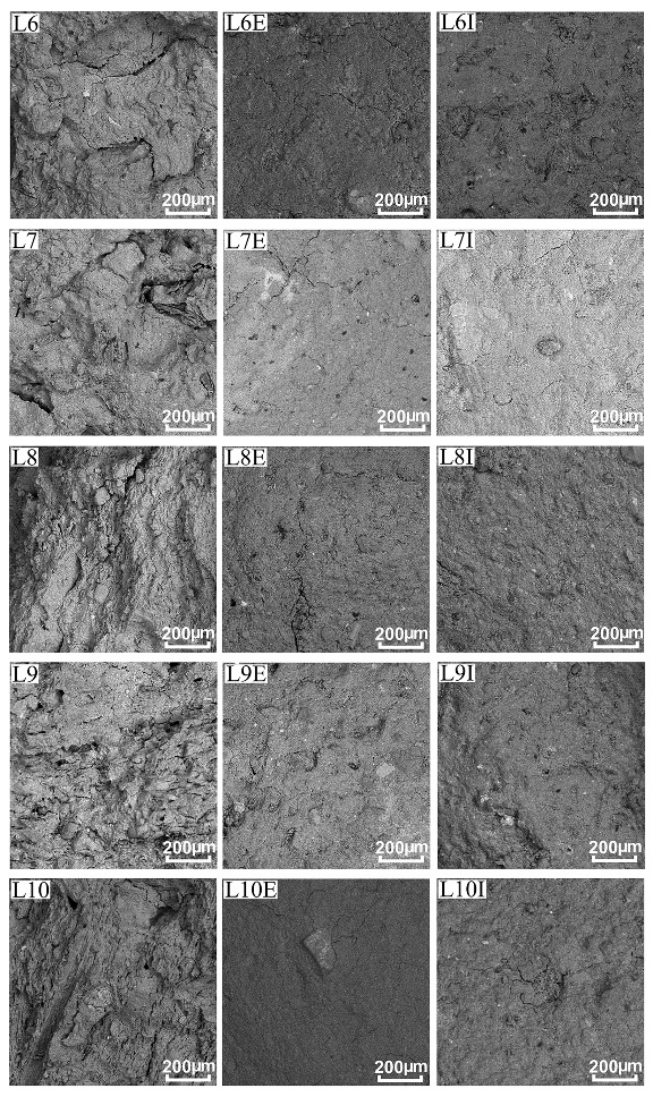

Figure 8. SEM micrographs for the Costișa ceramic fragments (L6-L10) from Piatra Neamț-Lutărie.
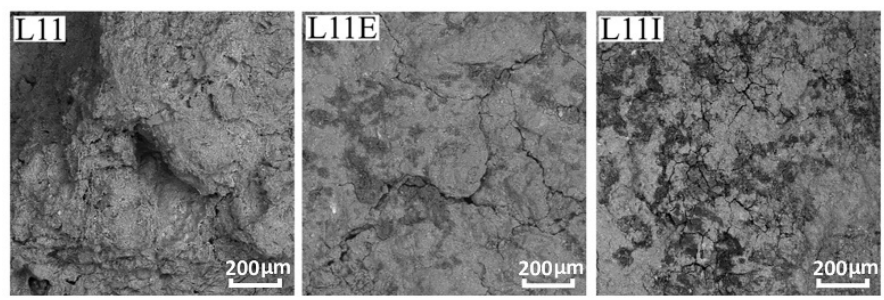

a

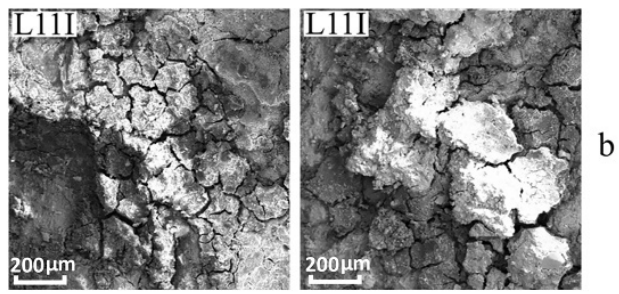

Figure 9. SEM micrographs for Monteoru sample L11 $(\mathbf{a}, \mathbf{b})$ details for the inner residues.

SEM analyses of the ceramic paste indicated that most of the samples have a low homogeneity, and the component microstructures were well individualized. The vitrification process was not observed in any sample, an indication that the firing temperatures have not exceeded $800-850{ }^{\circ} \mathrm{C}$ [31-33]. For five ceramic fragments, it was confirmed by SEM using the coiling technique in vessel manufacturing, a fact observed macroscopically for all vessels.

EDX analyses for ceramic paste were performed for all 11 samples taken from the Piatra Neamț-Lutărie. The chemical composition of the studied fragments contains the common elements found in clays, such as $\mathrm{Si}, \mathrm{Al}, \mathrm{P}, \mathrm{Mg}, \mathrm{Ca}, \mathrm{K}, \mathrm{Na}, \mathrm{Fe}, \mathrm{Ti}, \mathrm{O}$ or C [34-39]. The elements that are of interest in archaeometric studies are iron, calcium, phosphorus 
and carbon (Table 1). In pottery studies, these elements are considered significant because their presence in certain concentrations allows arguments about the type of clay (Fe $>4 \%$ ferruginous clay, $\mathrm{Ca}>5 \%$ calcareous clay), the firing temperature ( $\mathrm{C}$ is found in samples up to $750{ }^{\circ} \mathrm{C}$, and its presence in high concentration on the inner surface of the vessel may be due to the nature of the goods stored in the vessel) and the functionality of the vessels (the presence of $\mathrm{P}>2 \%$ demonstrates that the vessels were used in food preparation).

Table 1. Elemental composition of the ceramic fragments from the Piatra Neamț-Lutărie.

\begin{tabular}{cccccccccccc}
\hline \multirow{2}{*}{ Sample } & \multicolumn{10}{c}{ Elemental Composition in Weight Percent (\%) } \\
\cline { 2 - 12 } & $\mathbf{S i}$ & $\mathbf{A l}$ & $\mathbf{P}$ & $\mathbf{M g}$ & $\mathbf{C a}$ & $\mathbf{K}$ & $\mathbf{N a}$ & $\mathbf{F e}$ & $\mathbf{T i}$ & $\mathbf{C}$ & $\mathbf{O}$ \\
\hline L1 & 24.65 & 9.42 & 1.30 & 0.84 & 1.83 & 3.76 & 0.34 & 4.63 & 1.43 & - & 51.80 \\
L2 & 22.30 & 9.96 & 2.10 & 1.46 & 1.86 & 2.50 & 0.60 & 3.42 & 0.72 & 0.64 & 54.44 \\
L3 & 26.22 & 9.94 & 2.44 & 1.14 & 1.47 & 2.68 & 0.37 & 4.96 & 0.56 & 0.55 & 49.67 \\
L4 & 26.24 & 9.81 & 2.55 & 1.25 & 1.46 & 2.41 & 0.72 & 5.47 & 0.71 & - & 49.38 \\
L5 & 23.44 & 9.10 & 1.37 & 1.21 & 2.70 & 3.07 & 0.70 & 4.27 & 0.85 & - & 53.29 \\
L6 & 22.76 & 8.26 & 2.51 & 0.80 & 2.43 & 3.17 & 0.64 & 4.45 & 0.92 & 0.27 & 53.79 \\
L7 & 22.18 & 9.94 & 2.30 & 1.33 & 2.13 & 2.97 & 0.53 & 5.11 & 0.82 & 0.23 & 52.46 \\
L8 & 23.95 & 10.80 & 3.04 & 1.17 & 1.43 & 2.23 & 0.78 & 4.91 & 0.66 & - & 51.03 \\
L9 & 18.27 & 7.14 & 2.10 & 0.70 & 2.60 & 2.15 & 0.52 & 3.79 & 0.40 & 1.19 & 61.14 \\
L10 & 22.57 & 10.10 & 4.75 & 0.95 & 2.37 & 2.17 & 0.90 & 5.15 & 0.84 & 0.22 & 49.98 \\
\hline
\end{tabular}

The presence of iron and/or calcium indicates the nature of the clay used, which can be ferruginous $(4 \%)$ [36-39] or calcareous $(5 \%)[31,40]$. The analyzed samples have iron values from $3.42 \%$ to $5.97 \%$, which suggests using ferruginous clay in vessel manufacturing. Calcium is present in all samples, with concentrations not exceeding $2.70 \%$, so the presence of a calcareous clay is not detected. The Monteoru fragment (L11) has a higher calcium content $(4.13 \%)$, indicating a possible low calcareous clay.

Phosphorus values higher than $2 \%$ result from using a vessel for boiling or for storing liquids rich in phosphorus [41-43]. In the analyzed group, phosphorus has concentrations between 2.09 and 3.55\% for cooking vessels samples L2, L3, L4, L8, 2.30-2.51\% for storage vessels (L6, L7) and 2.10-4.70\% for serving vessels (L9, L10).

Carbon is present in the chemical composition of six samples, two for cooking (L2, L3), two for storage (L6, L7) and two for food serving (L9, L10). Concentrations are between 0.22 and $1.18 \%$, indicating that the firing temperature for these vessels did not exceed $700{ }^{\circ} \mathrm{C}[33,44]$.

\subsection{3. $\mu$ FTIR Analyses}

The $\mu$ FTIR analyses performed for all 11 samples showed similarities in terms of chemical compounds present in the raw clay used for pottery making. The appearance of the obtained spectra is the same, except for the L11 fragment, which is a feature that will be discussed at length (Figure 10).

The range $4000-3000 \mathrm{~cm}^{-1}$ is attributed to water [45], and the absorbed water [46,47] from the samples was also detected through obvious peaks from $\sim 3368 \mathrm{~cm}^{-1}$ and $\sim 1630 \mathrm{~cm}^{-1}$, corresponding to the $-\mathrm{OH}$ deformations, most likely as a result of deposition processes.

Kaolinite $\left(\mathrm{Al}_{2} \mathrm{Si}_{2} \mathrm{O}_{5}(\mathrm{OH})_{4}\right)$ was identified in almost all samples by peak position in the region 3500-3750 $\mathrm{cm}^{-1}[46,48,49]$. All fragments were fired at temperatures above $500{ }^{\circ} \mathrm{C}$, as indicated by the absence of the $915 \mathrm{~cm}^{-1}$ doublets $[46,50,51]$ of kaolinite, except for the L11 sample. 


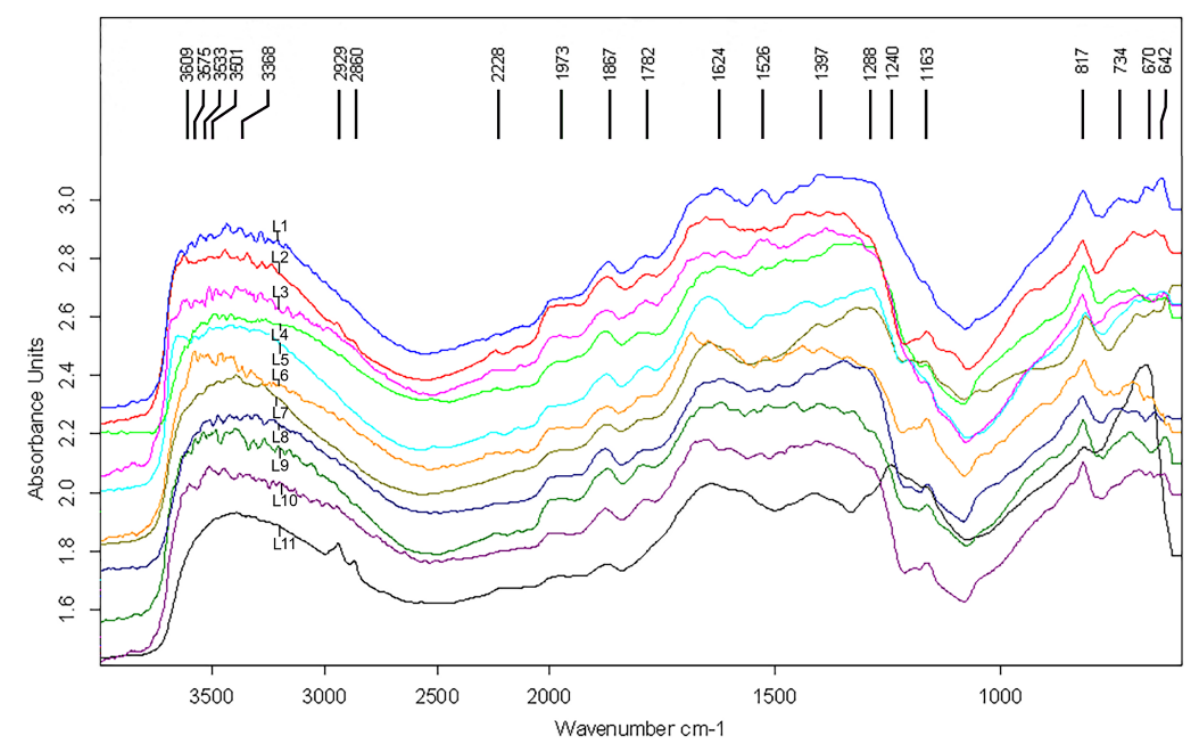

Figure 10. FT-IR spectra of the ceramic fragments from Piatra Neamț-Lutărie.

In all analyzed samples, calcite $\left(\mathrm{CaCO}_{3}\right)$ was identified by peaks at $2970 \mathrm{~cm}^{-1}$, $\sim 2936 \mathrm{~cm}^{-1}, \sim 2519 \mathrm{~cm}^{-1}, \sim 737 \mathrm{~cm}^{-1}$. In addition, the presence of carbonates [51,52] is visible from the broad band at $1300-1500 \mathrm{~cm}^{-1}$, which indicates that the firing temperatures of the vessels did not exceed $700-750{ }^{\circ} \mathrm{C}$ [51]. At $\sim 706 \mathrm{~cm}^{-1}$, aragonite was identified [53], the anhydrous variant of calcium carbonate, which was present in five samples (L2, L4, L6, L8, L9).

Silicates are represented by the Si-H stretching of quartz [45] in the region $1900-1870 \mathrm{~cm}^{-1}$, the representative peaks from $1973 \mathrm{~cm}^{-1}$ and $1870 \mathrm{~cm}^{-1}$ being visible in all samples. Moreover, quartz [48-50,54,55] was also identified at $2231 \mathrm{~cm}^{-1}, \sim 1162 \mathrm{~cm}^{-1}$ and $\sim 692 \mathrm{~cm}^{-1}$. Wollastonite [49] $\left(\mathrm{CaSiO}_{3}\right)$ was identified at $925 \mathrm{~cm}^{-1}$ in sample $\mathrm{L} 7$ and at $1055 \mathrm{~cm}^{-1}$ in the L8. In the same sample, the presence of diopside $\left.[49]\left(\mathrm{CaMg}_{[} \mathrm{Si}_{2} \mathrm{O}_{6}\right]\right)$ at $628 \mathrm{~cm}^{-1}$ was highlighted so that both identified minerals come from the raw clay. In addition, muscovite [56,57] $\left(\mathrm{KAl}_{3} \mathrm{Si}_{2} \mathrm{O}_{10}(\mathrm{OH})_{2}\right)$ is present in all samples at $1270-1272 \mathrm{~cm}^{-1}$ and $\sim 818 \mathrm{~cm}^{-1}$.

Feldspars are present at $\sim 1772 \mathrm{~cm}^{-1}$, establishing their alkaline nature by identifying the anorthoclase $[51,56]\left((\mathrm{NaK})\left[\mathrm{AlSi}_{3} \mathrm{O}_{8}\right]\right)$ at $\sim 667 \mathrm{~cm}^{-1}$ and albite $[49,51,58]\left(\mathrm{NaAlSi}_{3} \mathrm{O}_{8}\right)$ at $\sim 645 \mathrm{~cm}^{-1}$. Iron oxides [51] were detected in all samples at $\sim 656 \mathrm{~cm}^{-1}$.

The presence of feldspars is related to the aluminosilicates, potassium and magnesium from the EDX analysis. The presence of iron oxides identified by macro- and microscopy is also found in the $\mu$ FTIR spectra, which supports the ferruginous nature of clay established by EDX. The high phosphorus concentration identified by the EDX analysis and the lack of phosphates in the $\mu$ FTIR spectra supports the hypothesis on the origin of this element from vessel usage. Although no carbon was identified in some fragments, the correlation of EDX results with $\mu$ FTIR spectra indicated the presence of carbonates and calcite in all samples so that the firing temperatures did not exceed the decomposition limit of carbonates.

Thus, the EDX and $\mu$ FTIR analyses illustrate using a local clay that has the same mineralogical and physicochemical characteristics, and the firing temperatures of the vessels were below $500{ }^{\circ} \mathrm{C}$ for the L11 sample and between 550 and $600{ }^{\circ} \mathrm{C}$ and $700-750{ }^{\circ} \mathrm{C}$ for the rest of the samples.

\subsection{L11 and the Presence of Organic Residues}

The Monteoru fragment (L11) has a higher iron content (5.97\%) that suggests using the same ferruginous clay, but also the presence of an appreciable calcium content could indicate a low calcareous clay. The phosphorus concentration of this vessel is $5.23 \%$, most likely determined by the storage of substances with a high phosphorus content. 
The presence of a dark-colored layer identified macro- and microscopically is an indication in this regard.

In an attempt to determine the nature of the substance identified inside the vessel, several EDX analyses were performed, both on the outside (L11E), and in particular on the black layer (L11I), including at the interface with the vessel wall (L11I2) to eliminate the possible effects of contamination (Table 2).

Table 2. Elemental composition of the Monteoru fragment (L11) for ceramic paste and surfaces.

\begin{tabular}{|c|c|c|c|c|c|c|c|c|c|c|c|}
\hline \multirow{2}{*}{ Sample } & \multicolumn{11}{|c|}{ Elemental Composition in Weight Percent (\%) } \\
\hline & $\mathrm{Si}$ & Al & $\mathrm{C}$ & $\mathbf{P}$ & $\mathrm{Mg}$ & $\mathrm{Ca}$ & K & $\mathrm{Na}$ & $\mathrm{Fe}$ & $\mathrm{Ti}$ & $\mathbf{O}$ \\
\hline L11 & 12.14 & 7.95 & 7.07 & 5.23 & 1.14 & 4.13 & 1.68 & 0.80 & 5.97 & 0.49 & 53.40 \\
\hline L11 E & 7.55 & 2.83 & 16.96 & 0.37 & 0.26 & 3.18 & 1.55 & 0.10 & 3.96 & 0.47 & 62.77 \\
\hline L11 I & 7.85 & 2.95 & 22.21 & 1.47 & 0.35 & 5.32 & 1.56 & 0.12 & 4.49 & 0.40 & 53.28 \\
\hline L11 I 2 & 5.68 & 2.53 & 22.91 & 1.43 & 0.40 & 6.63 & 1.77 & 0.28 & 2.77 & 0.54 & 55.06 \\
\hline
\end{tabular}

The compositional results show, in addition to the elements specific to the raw material, the presence of a very high concentration of carbon, which at the interface with the vessel wall is up to $22.9 \%$. This value certainly indicates that this element is organic in nature. Moreover, the carbon appears to have migrated from the inside to the outside, penetrating the vessel wall, which precludes possible contamination. To clarify the SEM-EDX results, an analysis was performed by infrared spectroscopy for the ceramic paste and surfaces (Figure 11).

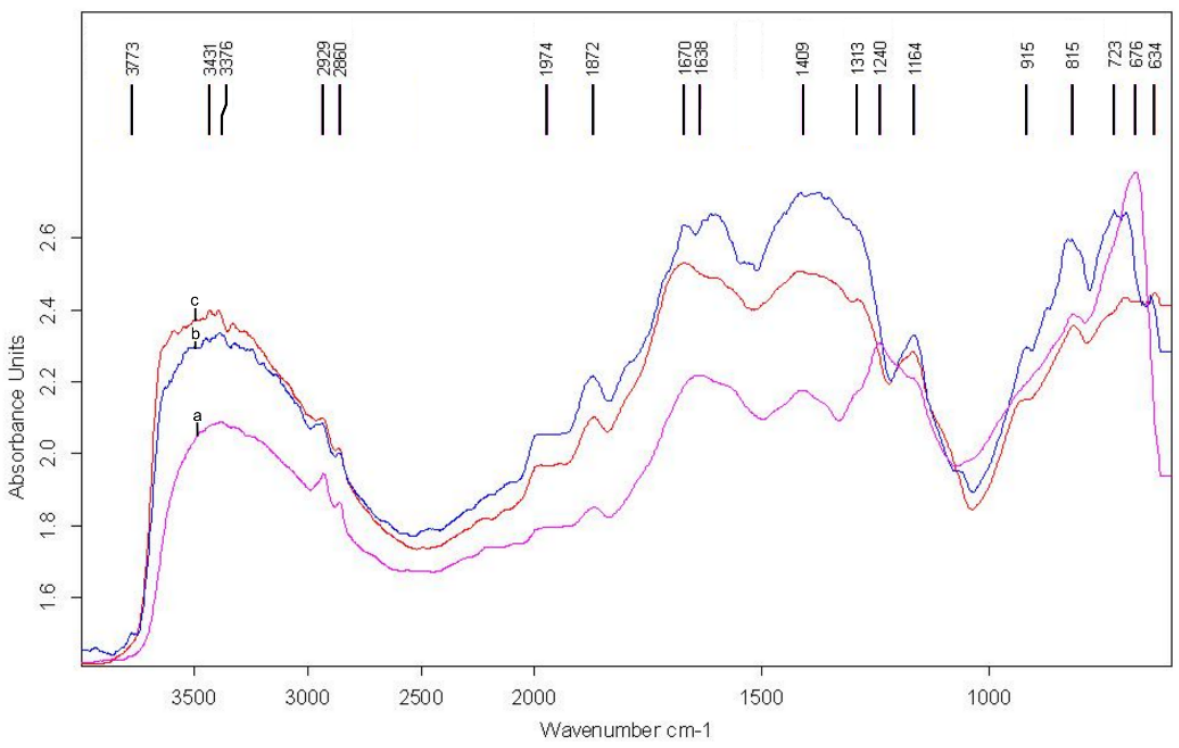

Figure 11. FT-IR spectra for sample L11 (a) ceramic paste; (b) outer surface; (c) inner surface.

Thus, for the paste of the L11 sample, montmorillonite [51] ((Na,Ca $)_{0.33}(\mathrm{Al}, \mathrm{Mg})_{2}$ $\left.(\mathrm{Si} 4 \mathrm{O} 10)(\mathrm{OH})_{2} \cdot \mathrm{nH}_{2} \mathrm{O}\right)$ were identified mainly by the presence of the central peak at 3376 $\mathrm{cm}^{-1}$, from the specific range $3300-3500 \mathrm{~cm}^{-1}$. In addition, the inner surface spectrum shows the presence of kaolinite $[46,48,49]$ at $3562 \mathrm{~cm}^{-1}$. The presence of the doublets at $915 \mathrm{~cm}^{-1}$, attributed to $\mathrm{OH}$ deformations of kaolinite, is visible up to temperatures of 500 ${ }^{\circ} \mathrm{C}$, after which it disappears $[46,50,51]$. It is important to mention that the vessel has a ceramic slip applied on the exterior, which is made of the same type of clay as the vessel. There is also the possibility of an inner slip that was not noticed due to the black layer covering the entire inner surface of the vessel. The intense peaks from $2929 \mathrm{~cm}^{-1}$ and $2860 \mathrm{~cm}^{-1}$ are attributed to the organic carbon [47,50,55,59-61], present on the surfaces but also in the paste, this being the result of the blackish substance identified on the vessel. Metal carboxylates at $\sim 1409^{-1}$ and oxalates $\sim 1313 \mathrm{~cm}^{-1}$ may derive from the degradation 
of some organic compounds. In this regard, it is worth noting that the stretching of $\mathrm{C}-\mathrm{H}$ contributions appearing in the same spectrum at $\sim 2860 \mathrm{~cm}^{-1}$ and $\sim 2929 \mathrm{~cm}^{-1}$ support the presence of a protein material subjected to degradation processes $[62,63]$. The other minerals identified by the $\mu$ FTIR analysis of the L11 sample are the same as in the case of Costișa samples and will not be repeated.

The results of the chemical analyses highlighted using the coiling technique in the process of pottery manufacturing, as well as the effect of the luster on the surfaces, a technique of closing the ceramic pores, while the ceramic slip or only finished surfaces have visible pores and mineral elements partially integrated into the clay.

All vessels were made of ferruginous clay whose mineralogy indicates using a local source. The containers were fired at temperatures between 550 and $600{ }^{\circ} \mathrm{C}$ and $700-750{ }^{\circ} \mathrm{C}$. The presence of phosphorus confirmed the functionality of cooking vessels and indicated that storage and serving vessels were also used for cooking or storage of phosphorus-rich substances [64]. The Monteoru vessel (L11) was also manufactured from ferruginous clay, being fired at temperatures that did not exceed $500{ }^{\circ} \mathrm{C}$. The chemical composition of the Monteoru fragment indicates using two types of clay, one for making the vessel and another for the ceramic slip.

\section{Conclusions}

The present archaeometric study generated a series of general data for the pottery from Piatra Neamț-Lutărie settlement. Thus, all the pots were made of local kaolinitic clay, by the coiling technique, with well-finished and smoothed surfaces, burnished or covered with a ceramic slip, treatments adapted according to the functionality of the vessels. The physicochemical analysis indicated that the two communities used the same source of raw material located in the vicinity of the settlement, which shows that the potters preferred the immediate and effortless source. In this sense, the positioning of the settlement was made taking into account several factors, including the proximity of water and clay reserves necessary for the manufacture of pottery.

The inclusions used in the manufacture of vessels are ceramoclasts, which, depending on their size, shape and frequency, led to identifying three types of paste correlated with certain functional categories. The use of ceramoclasts demonstrates the knowledge of their thermal properties by the Costișa and Monteoru potters. Moreover, using reused ceramoclasts could have a dual role, one of a practical nature, which involves integrating damaged containers into the paste of new vessels and would constitute a "recycling" system and a special one, which could represent the conservation of cultural ideas and identities.

Pyrotechnology information, both at the macroscopic level and through the interdisciplinary study, suggests an uncontrolled firing, with temperatures between 550 and $700{ }^{\circ} \mathrm{C}$. The identification of relatively low-temperature ranges, together with the variety of colors of the vessels and the uneven atmosphere, indicates that the pottery was fired in pits or above ground.

To conclude, using the methods applied in this paper, we found no notable differences in the pottery of these two communities. The manufacturing techniques, including using the same source of clay, finishing treatments and firing pottery technologies, are the same, suggesting ordinary contacts between Costișa and Monteoru ceramic groups in the interference zone of Eastern Romania. The typology of pottery, details of the chemical composition, physical characteristics, macro- and microscopic observations suggest the existence of a stable community, which has the same technological skills for producing the usual pottery of a Middle Bronze Age community.

Author Contributions: Conceptualization, A.D., V.V. and N.B.; methodology, A.D., N.B.; validation, V.V. and A.D.; investigation, V.V., A.D.; writing-original draft preparation, A.D., V.V., N.B.; All authors have read and agreed to the published version of the manuscript. 
Funding: This work was co-funded by the European Social Fund, through Operational Programme Human Capital 2014-2020, project number POCU/380/6/13/123623, project title "PhD Students and Postdoctoral Researchers Prepared for the Labor Market!".

Institutional Review Board Statement: Not applicable.

Informed Consent Statement: Not applicable.

Data Availability Statement: All required data provided in the manuscript.

Acknowledgments: We would like to thank Ciprian-Dorin NECULA, the director of the Neamt County Museum Complex, for the access to the archaeological material.

Conflicts of Interest: The authors declare no conflict of interest.

\section{References}

1. Bolohan, N. "All in one". Issues of Methodology, Paradigms and Radiocarbon Datings Concerning the Outer Eastern Carpathian Are. In Signa Praehistorica. Studia in Honorem Magistri Attila László Septuagesimo Anno. Honoraria, 9; Bolohan, N., Mătău, F., Tencariu, A.F., Eds.; Editura Universității „Alexandru Ioan Cuza” din Iași: Iași, Romania, 2010; pp. 229-244.

2. Popescu, A.; Băjenaru, R. From the Middle Danube to Anatolia: Contacts During the Second Millennium BC. A Case Study. In SOMA 2011, Proceedings of the 15th Symposium on Mediterranean Archaeology, University of Catania, Catania, Italy, 3-5 March 2011; Militello, P.M., Öniz, H., Eds.; BAR IS 2695 (I): Oxford, UK, 2015; pp. 35-43.

3. Bolohan, N.; Gafincu, A.; Stoleriu, I. Middle Bronze Age Chronology East of the Carpathian Area. A Bayesian Model. In Bronze Age Chronology in the Carpathian Basin, Proceedings of the International Colloquium from Târgu Mures, Romania, 2-4 October 2014; Németh, R.E., Rezi, B., Eds.; Editura Mega: Târgu Mureș, Romania, 2015; pp. 131-146.

4. Vulpe, A. Voice Costișa. In Enciclopedia Arheologiei și Istoriei Vechi a României 1 (A-C); Preda, C., Ed.; Editura Enciclopedică: București, Romania, 1994; p. 362.

5. Vulpe, A. Perioada Mijlocie a Epocii Bronzului. In Istoria Românilor I, Moștenirea Timpurilor Îndepărtate, 2nd ed.; revised; PetrescuDîmbovița, M., Vulpe, A., Eds.; Editura Enciclopedică: București, Romania, 2010; pp. 244-265.

6. Bolohan, N. Recent Discoveries Belonging to Early/Middle Bronze Age in Central Moldavia. Arh. Mold. 2003, $26,195-206$.

7. Bolohan, N.; Cretu, C. Recent Discoveries Belonging to Early/Middle Bronze Age in Central Moldova. In Thracians and Circumpontic World; Niculiță, I., Zanoci, A., Băț, M., Eds.; Cartdidact: Chișinău, Moldavia, 2004; pp. 55-76.

8. Popescu, A.-D.; Băjenaru, R. Rivalries and conflicts in the bronze age: Two contemporary communities in the same space. Dacia NS 2009, 52, 5-22.

9. Nițu, A.; Zamoșteanu, I.; Zamoșteanu, M. Sondajele de la Piatra-Neamț. MCA 1959, 6, 359-374.

10. Diaconu, V. Repertoriul Descoperirilor Atribuite Epocii Bronzului din Județul Neamț; Editura "Constantin Matasă": Piatra-Neamt, Romania, 2016.

11. Geological Map of Romania, Scale 1:200000; Editura Institutului Geologic al României: București, Romania, 1968.

12. Soil Map of Romania, Scale 1:1000000; Institutul de Geodezie, Fotogrammetrie, Cartografie și Organizarea Teritoriului: București, Romania, 1978.

13. Prehistoric Ceramics Research Group. The Study of Prehistoric Pottery: General Policies and Guidelines for Analysis and Publication, 3rd ed.; Wessex Archaeology Ltd.: Salisbury, UK, 2010.

14. Rice, P.M. Pottery Analysis: A Sourcebook; University of Chicago Press: Chicago, IL, USA, 1987.

15. Vuković, J. Archaeological Evidence of Pottery Forming Sequence: Traces of Manufacture in Late Neolithic Vinća Assemblage. In Archaeotechnology: Studying Technology from Prehistory to the Middle Ages; Vitezović, S., Antonović, D., Eds.; DC Grafički Centar: Belgrade, Serbia, 2014; pp. 177-199.

16. Roux, V. La Technique du Tournage: Définition et Reconnaissance par les Macrotraces. In Terre Cuite et Société. La Céramique, Document Technique, Économique et Culturel. XIVe Rencontres Internationales d'Archéologie et d'Histoire d'Antibes; Audouze, F., Binder, D., Eds.; Editions APDCA: Juan-les-Pins, France, 1994; pp. 45-58.

17. Joukowsky, M. A Complete Manual of Field Archaeology, Tools and Techniques of Field Work for Archaeologists; Prentice-Hall INC: New Jersey, NJ, USA, 1980.

18. Henrickson, E.; McDonald, M.M.A. Ceramic form and Function: An Ethnographic Search and an archaeological Application. Am. Anthropol. 1983, 85, 630-643. [CrossRef]

19. Bodi, G.; Solcan, L. Considerații asupra unei posibile tipologii funcționale a formelor ceramice cucuteniene specifice fazei A. Arh. Mold. 2010, 33, 315-323.

20. Forte, V.; Cesaro, S.N.; Medeghini, L. Cooking traces on Copper Age pottery from central Italy: An integrated approach comparising use wear analysis, spectroscopic analysis and experimental archaeology. JAS Rep. 2018, 18, 121-138. [CrossRef]

21. Vitelli, K.D. Were pots first made for foods? Doubts from Franchthi. World Archaeol. 1989, 21, 17-29. [CrossRef]

22. Orton, C.; Tyres, P.; Vince, A. Pottery in Archaeology; Cambridge University Press: London, UK, 1993.

23. Rye, O.S. Pottery Technology, Principles and Reconstruction (Manuals on Archaeology); Taraxacum: Washington, WA, USA, 1981. 
24. Ionescu, C.; Hoeck, V. Ceramic technology. How to investigate surface finishing. Archaeol. Anthrop. Sci. 2020, 12, 204-220. [CrossRef]

25. Tite, M.S. Ceramic production, provenance and use-a review. Archaeometry 2008, 50, 216-231. [CrossRef]

26. Ionescu, C.; Ghergari, L. Mic glosar de termeni geologici utilizați în studiul ceramicii arheologice. CA 2006, 33, 451-460. [CrossRef]

27. Kreiter, A. Technological Choices and Material Meanings in Early and Middle Bronze Age Hungary: Understanding the Active Role of Material Culture through Ceramic Analysis; BAR IS 1604, Archaeopress: Oxford, UK, 2007.

28. Skibo, J.M.; Schiffer, M.B.; Reid, K.C. Organic-tempered pottery: An experimental study. Am. Antiq. 1989, 54, 122-146. [CrossRef]

29. Palanivel, R.; Meyvel, S. Microstructural and microanalytical study-(SEM) of archaeological pottery artifacts. Rom. J. Phys. 2010, 55, 333-341.

30. Łaciaka, D.; Borowskib, M.P.; Łydżba-Kopczyńskac, B.; Barona, J.; Furmaneka, M. Archaeometric characterization and origin of black coatings on prehistoric pottery. Geochem. Int. 2019, 79, 453-466. [CrossRef]

31. Maniatis, Y.; Tite, M.S. Technological Examination of Neolithic-Bronze Age Pottery from Central and Southeast Europe and from the Near East. J. Archaeol. Sci. 1981, 8, 59-76. [CrossRef]

32. Karapukaitytè, A.; Pakutinskienė, I.; Tautkus, S.; Kareiva, A. SEM and EDX characterization of ancient pottery. Lith. J. Phys. 2006, 46, 383-388. [CrossRef]

33. Amicone, S.; Radivojević, M.; Quinn, P.S.; Berthold, C.; Rehren, T. Pyrotechnological connections? Re-investigating the link between pottery firing technology and the origins of metallurgy in the Vinča Culture, Serbia. J. Archaeol. Sci. 2020, 11, 1-19. [CrossRef]

34. Sandu, I.; Vasilache, V.; Tencariu, F.A.; Cotiugă, V. Conservarea Științifică a Artefactelor din Ceramică; Editura Universității „,Alexandru Ioan Cuza": Iași, România, 2010.

35. Sandu, I.; Cotiugă, V.; Sandu, A.V.; Ciocan, A.C.; Olteanu, G.I.; Vasilache, V. New archaeometric characteristics for ancient pottery identification. Int. J. Conserv. Sci. 2010, 1, 75-82.

36. Vasilache, V.; Sandu, I.; Enea, S.C.; Sandu, I.G. Determinări ceramografice pe loturi din siturile Costești și Giurgești. In Comunitățile Cucuteniene din Zona Târgului Frumos: Cercetări Interdisciplinare în Siturile de la Costești și Giurgești; Boghian, D., Enea, S.C., Ignătescu, S., Stanc, S.M., Eds.; Editura Universității „Alexandru Ioan Cuza”: Iași, Romania, 2014; pp. 138-147.

37. Crupi, V.; Kasztovszky, Z.; Khalilli, F.; La Russa, M.F.; Macchia, A.; Majolino, D.; Rossi, B.; Rovella, N.; Ruffolo, S.A.; Venuti, V. Evaluation of complementary methodologies applied to a preliminary archaeometric study of glazed pottery from Agsu (Azerbaijan). Int. J. Conserv. Sci. 2016, 7, 901-912.

38. Sharmin, D. Technological Interpretation of Traditional Ceramic Materials on Thin-Section Petrography. Int. J. Conserv. Sci. 2020, 11, 539-556.

39. Sandu, I.G.; Vasilache, V.; Cotiugă, V. Revaluation of archaeological ceramics assets under generally accepted principles of integrated scientific conservation. Int. J. Conserv. Sci. 2010, 1, 241-247.

40. Ravisankar, R.; Kiruba, S.; Shamira, C.; Naseerutheen, A.; Balaji, P.D.; Seran, M. Spectroscopic techniques applied to characterization of recently excavated ancient potteries from Thruverkadu Tamilandu, India. Microchem. J. 2011, 99, 370-375. [CrossRef]

41. Duma, G. Phosphate Content of Ancient Pots as Indication of Use. Curr. Anthropol. 1972, 13, 127-130. [CrossRef]

42. Béarat, H.; Dufournier, D. Quelques expériences sur la fixation du phosphore par les céramiques. Revue d'Archéométrie 1972, 18, 65-73. [CrossRef]

43. Santos Rodrigues, S.F.; Lima da Costa, M. Phosphorus in archaeological ceramics as evidence of the use of pots for cooking food. Appl. Clay Sci. 2016, 123, 224-231. [CrossRef]

44. Bong, W.S.K.; Matsumura, K.; Nakai, I. Firing Technologies and Raw Materials of Typical Early and Middle Bronze Age Pottery from Kaman-Kalehöyük: A Statistical and Chemical Analysis. Anatol. Stud. 2008, 17, 295-311.

45. Aroke, U.O.; Abdulkarim, A.; Ogubunka, R.O. Fourier-transform Infrared Characterization of Kaolin, Granite, Bentonite and Barite. ATBU J. Environ. Technol. 2013, 6, 42-53.

46. Frost, R.L.; Vassallo, A.M. The dehydroxylation of the kaolinite clay minerals using infrared emission spectroscopy. Clays Clay Miner. 1996, 44, 635-651. [CrossRef]

47. Damjanović, L.; Holclajtner-Antunović, I.; Mioć, U.B.; Bikić, V.; Milovanović, D.; Radosavlkević Evans, I. Archaeometric study of medieval pottery excavated at Stari (old) Ras, Serbia. J. Archaeol. Sci. 2011, 38, 818-828. [CrossRef]

48. Chen, Y.; Zou, C.; Mastalerz, M.; Hu, S.; Gasaway, C.; Tao, X. Applications of Micro-Fourier Transform Infrared Spectroscopy (FTIR) in the Geological Sciences-A Review. Int. J. Mol. Sci. 2015, 16, 30223-30250. [CrossRef]

49. Oancea, A.V.; Bodi, G.; Nica, V.; Ursu, L.E.; Drobota, M.; Cotofana, C.; Vasiliu, A.L.; Simionescu, B.C.; Olaru, M. Multi-analytical characterization of Cucuteni pottery. J. Eur. Ceram. 2017, 37, 5079-5098. [CrossRef]

50. Velraj, G.; Janaki, K.; Mustafa, A.M.; Palanivel, R. Estimation of firing temperatures of some archaeological pottery sherds excavated recently in Tamilandu, India. Spectrochim. Acta A Mol. Biomol. Spectrosc. 2009, 72, 730-733. [CrossRef]

51. Ravisankar, R.; Kiruba, S.; Eswaran, P.; Senthilkumar, G.; Chandrasekaran, A. Mineralogical Characterization Studies of Ancient Potteries of Tamilnadu, India by FT-IR Spectroscopic Technique. E-J. Chem. 2010, 7, S185-S190. [CrossRef]

52. Nodari, L.; Marcuz, E.; Maritan, L.; Mazzoli, C.; Russo, U. Hematite nucleation and growth in the firing of carbonate-rich clay for pottery production. J. Eur. Ceram. 2007, 27, 4665-4673. [CrossRef] 
53. Gasaway, C.; Mastalerz, M.; Krause, F.; Clarkson, C.; Debuhr, C. Applicability of Micro-FTIR in Detecting Shale Heterogenity. Microscopy 2017, 265, 60-72. [CrossRef] [PubMed]

54. Palanivel, R.; Kumar, U.R. Thermal and spectroscopic analysis of ancient potteries. Rom. J. Phys. 2011, 56, 195-208.

55. Kumar, R.S.; Rajkumar, P. Characterization of minerals in air dust particles in the state of Tamilandu, India through FTIR Spectroscopy. Infrared Phys. Tchenol. 2014, 67, 30-41. [CrossRef]

56. Barilaro, D.; Barone, G.; Crupi, V.; Majolino, D.; Mazzoleni, P.; Tigano, G.; Venuti, V. FT-IR absorbance spectroscopy to study Sicilian "proto-majolica" pottery. Vib. Spectrosc. 2008, 48, 269-275. [CrossRef]

57. Vasilache, V.; Kavruk, V.; Tencariu, F.A. OM, SEM-EDX, and micro-FTIR analysis of the Bronze Age pottery from the Băile Figa salt production site (Transylvania, Romania). Microsc. Res. Tech. 2020, 83, 604-617. [CrossRef]

58. Akyuza, S.; Guliyev, F.; Celik, S.; Ozel, A.E.; Alakbarov, V. Investigations of the Neolithic potteries of 6th millennium BC from Goytepe-Azerbaijan by vibrational spectroscopy and chemometric techniques. Vib. Spectrosc. 2019, 105, 102980. [CrossRef]

59. Columbini, M.P.; Giachi, G.; Modugno, F.; Ribechini, E. Characterization of organic residues in pottery vessels of Roman age from Antinoe (Egypt). Microchem. J. 2005, 79, 83-90. [CrossRef]

60. Maritan, L.; Mazzoli, C.; Nodari, L.; Russo, U. Second Iron Age grey pottery from Este (northeastern Italy): Study of provenance and technology. Appl. Clay Sci. 2005, 29, 31-44. [CrossRef]

61. Costa, T.G.; de Correia, M.D.M.; Reis, L.B.; dos Santos, S.S.; Machado, J.S.; Bueno, L.; da Silva Müller, I. Spectroscopic characterization of recently excavated archaeological potsherds of Taquaea/Itararé tradition from Tobias Wagner site (Santa Catarina-Brazil). J. Archaeol. Sci. Rep. 2017, 12, 561-568.

62. Torrisi, L.; Venuti, V.; Crupi, V.; Silipigni, L.; Cutroneo, M.; Paladini, G.; Torrisi, A.; Havránek, V.; Macková, A.; La Russa, M.F.; et al. RBS, PIXE, Ion-Microbeam and SR-FTIR Analyses of Pottery Fragments from Azerbaijan. Heritage 2019, 2, 1852-1873. [CrossRef]

63. Sotiropoulou, S.; Papliaka, Z.E.; Vaccari, L. Micro FTIR imaging for the investigation of deteriorated organic binders in wall painting stratigraphies of diferent techniques and periods. Microchem. J. 2016, 124, 559-567. [CrossRef]

64. Bolohan, N. On Clay and Pots in the Middle Bronze Age. A case Study from Siliștea-Pe Cetățuie, Neamț County. In Bronze Age Crafts and Craftsmen in the Carpathian Basin, Proceedings of the International Colloquium from Târgu Mures, Romania, 5-7 October 2012; Rezi, B., Németh, R.E., Berecki, S., Eds.; Editura Mega: Târgu Mureș, Romania, 2013; pp. 33-56. 